\title{
Nanoyapılı İletken Dolgulu Polimer ile Geniş Bant Çok Katmanlı Radar Soğurucu Malzemelerin Geliştirilmesi
}

\author{
Hasan Kasım ${ }^{1 *}$ \\ ${ }^{1 *}$ Emsa Nano Teknoloji Enerji San. Ve Tic. A.Ş, , Bursa, Turkey, (ORCID: 0000-0002-3024-5207), hasankasim@emsaglobal.com
}

(İlk Geliş Tarihi 10 Ağustos 2021 ve Kabul Tarihi 29 Eylül 2021)

(DOI: 10.31590 /ejosat.993729)

ATIF/REFERENCE: Kasım, H. (2021). Nanoyapılı İletken Dolgulu Polimer ile Geniş Bant Çok Katmanlı Radar Soğurucu Malzemelerin Geliştirilmesi. Avrupa Bilim ve Teknoloji Dergisi, (27), 588-597.

Öz

$\mathrm{Bu}$ çalışma, nano boyutlu iletken dolgu malzemeleri kullanılarak hazırlanan Elastomer Esaslı Radar Soğurucu Malzemelerin (H-RGC), 0-360 arasında $3^{\circ}$ 'lik adımlar ile 6-17 GHz frekans bant aralığındaki Radar Kesit Alanı (RSA) azaltma verimliliği ve performansını karakterize etmek için karşılaştırmalı deneysel metodoloji sunmaktadır. Karşılaştırma kapsamında kullanılan referans malzeme (M-REM) askeri kara araçlarının (tank, kamyon, gemi vb.) radar kesit alanını azaltmak için tasarlanmış olup hali hazırda ticari olarak satılmaktadır. Çalışma kapsamında mükemmel geniş bant özellikleri sergileyen, her iki yönde yansıtıcı yüzey içeren 6 katmanlı, simetrik ve ince radar soğurucu malzeme tasarlanmış ve üretilmiştir. Karbon siyahı ve grafen nanoplatetler, sırasıyla yansıtıcı yüzey ve hibrit katmanı oluşturmak için gerekli kauçuk kompozit üretmek için kullanılmıştır. Her iki malzeme için yapılan ölçümlerde benzer sonuçlar elde edilmiş olup üretilen malzemenin gemi, askeri kara araçları gibi sistemlerde RSA azaltımında kullanılabileceğini görülmüştür. Sonuçlar, her iki malzeme tipinin de $20 \mathrm{dBsm}$ değerinde bir azaltım sağlayabildiğini göstermiştir. M-REM için frekanstan bağımsız olarak en iyi RSA değerleri $24-72^{\circ}$ arasında elde edilmişken, H-RGC için 21-72 aralığındadır. Her iki malzeme için frekans bant genişliği artıkça RSA değerlerinin de iyileştiği görülmüştür. M-REM için $12 \mathrm{GHz}$ frekans da yapılan testlerde en düşük soğurma değeri $72^{\circ} \mathrm{de}, 42,6743 \mathrm{dBsm}, \mathrm{H}-\mathrm{RGC}$ için ise 42,9219 dBsm olarak ölçülmüştür. Ticari olarak kullanılan ve geçerliliğini kanıtlamış M-REM'e alternatif olarak üretilen H-RGC malzemelerinin ölçüm sonuçları arasındaki benzerlik ve eşleşme, tasarımımızın geçerliliğini göstermiş ve ileri de yapılacak çalışmalar için umut verici sonuçlar elde edilmiştir.

Anahtar Kelimeler: Radar Soğurma Malzemesi, Radar Kesit Alanı Azaltımı, Elastomer, İletkenlik Özellikleri,

\section{Development of Broadband Multilayer Radar Absorber Materials With Nanostructured Conductive Filled Polymer}

\begin{abstract}
In this study, elastomer-based radar absorber materials (H-RGCs) prepared using nano-sized conductive fillers present a comparative experimental methodology to characterize the cross-sectional radar field (RSA) reduction efficiency and performance in the 6-17 GHz band with $3^{\circ}$ steps from 0 to $360^{\circ}$. The reference material (M-REM) used in the comparison is designed to reduce the radar crosssection area of military land vehicles (tank, truck, ship, etc.) and is currently commercially available. Within the scope of the study, a 6-layer, symmetrical and thin radar absorber material with reflective surfaces in both directions, exhibiting excellent broadband properties, was designed and manufactured. Carbon black and graphene nanoplatelets were used to produce the required rubber composite to form the reflective surface and hybrid layer. Similar results were obtained in the measurements made for both materials, and it was seen that the produced material could be used in systems such as ships and military land vehicles for RSA reduction. The results showed that both material types could achieve a reduction of $20 \mathrm{dBsm}$. The best RSA values, regardless of frequency, are obtained between $24-72^{\circ}$ for M-REM, while for H-RGC, it is in the range of $21-72^{\circ}$. It was observed that the RSA values improved as the frequency bandwidth increased for both materials. In the tests performed at $12 \mathrm{GHz}$ frequency for M-REM, the lowest absorption value was measured at $72^{\circ}, 42.6743 \mathrm{dBsm}$, and the lowest absorption value for H-RGC was $42.9219 \mathrm{dBsm}$. The similarity and match between the measurement results of the H-RGC materials produced as an alternative to the commercially used and proven M-REM showed the validity of our design and gave promising results for future studies.
\end{abstract}

Keywords: Radar Absorbing Material, Radar Cross Section Reduction, Elastomer, Conductivity Properties, Composites.

* Sorumlu Yazar: hasankasim@emsaglobal.com 


\section{Giriş}

Radar Soğurucu Malzemeler (RAM), günümüzde, optimizasyon ve radar algılama gibi askeri uygulamalardan modern yaşamın tüm alanlarına kadar bir çok yerde elektroteknik, elektronik ve radyo-elektronik sistemlerin elektromanyetik uyumluluğunun sağlanması noktasında yaygın olarak kullanılmaktadır. $\mathrm{Bu}$ malzemeler elektromanyetik dalgaları etkili bir şekilde emerek oluşan elektromanyetik enerjiyi ısıya dönüştüren yada elektromanyetik dalgaları bir parazit tarafından yok edebilen fonksiyonel kompozit yapılardır. $\mathrm{Bu}$ yapıyı oluşturan malzemelerin düşük yoğunluklu, diş zorlanmalara karşı dayanıklı ve uzun hizmet ömrüne sahip olması istenmektedir. Radar soğurucu yapıların tasarımlarında tek katmanlı veya tek tip soğurucu malzemeler (Li ve ark., 2010) yerine, mümkün olan en düşük kalınlığa sahip, çok katmanlı yapılardan (Park ve ark., 2006; Ren ve ark., 2012) oluşan, en geniş çalışma bant genişliği ile mümkün olan en düşük yansıma özelliklerine sahip kompozit soğurucu (Liu ve ark., 2008; Xu ve ark., 2016) yapıların tasarlanması son zamanlarda bir çok çalışmada ilgi odağ 1 haline gelmiştir. Bu sayede askeri amaçlı bir çok uygulama kapsamında Radar Kesit Alanı (RSA) azaltma çalışması yapılmaktadır. RSA bir cisim üzerine gelen elektromanyetik dalgaları yansıtma miktarının ölçüsü olarak tanımlanmaktadır (Knott ve ark., 2004).

Bir radar sinyali ile uyarılan cisim yüzeyinde oluşan akım, elektromanyetik dalgaları farklı yönlere saçarak yansıyan dalgaları oluşturur. $\mathrm{Bu}$ dalgalardan radar yönüne dönen yank1 dalgaları en önemlisidir (Badawy ve ark., 2020; Zhang ve ark., 2017). Yansıma yapan dalgalar ve RSA, akım yönü ve şiddetine, cismin geometrik şekline, malzeme özelliklerine, açı, frekans ve polarizasyona bağlıdır. Radar tespit ve görüntüleme sistemleri açısından RSA'nın düşük olması cismin daha zor tespit edilmesini ve izlenmesini sağlar.

Büyük elektromanyetik dalga soğurma performansına sahip kompozit malzemeler geliştirmek için birçok araştırma yapılmıştır. Bu çalışmalarda daha ince bir malzeme kalınlığı ve bant genişliğine sahip ultra ince radar soğurucu malzeme tasarlamak için alt tabaka olarak manyetik özelliklere sahip malzemeler kullanılmıştır (Kazantsev ve ark., 2010). Manyetik olmayan direnç yüklü çift kare halka döngülü metal malzemeleri, iki boyutlu ve periyodik olarak kompozit malzemelere gömerek ince ve geniş bantlı radar soğurucu malzemeler hazırlanmıştır (Shang ve ark., 2013). EPDM ile polianilin iletken polimeri karıştırılarak hazırlanan farklı konsantrasyonlardaki karışımların, 8-12 GHz frekans aralıklarında X-bandı saçılma ölçümleri ve dielektrik sabitleri belirlenerek uçağın radar kesitini azaltmak için havacılık amaçlı uygulamalar yapılmıştır (Franchitto ve ark., 2001). Poliakrilonitril ve poli (etilen tereftalat) alt tabakalarından oluşan dokunmamış malzeme üzerine polianilin ve poliüretan karışımı emdirilerek elde edilen çok katmanlı radar emici kompozit yapıların 8 ile $12 \mathrm{GHz}$ frekans aralığında yapılan deneylerde $\% 87$ ile \%99 arasında gelen elektromanyetik dalgaların emildiği gösterilmiştir (Folgueras ve ark., 2008). Grafit dolgulu epoksi karışımlar değişik kalınlıklarda hazırlanmış ve geri dönüş kaybı açısından değerlendirilmiştir. Kompozit matris içerisindeki grafit dolgu miktarının artması ile eşleştirme frekansının aşağıya doğru kaydığı, hazırlanan kompozitlerin iyi bir kompleks geçirgenlik, dielektrik tanjant kaybı ile gizli uygulamalarda radar soğurma malzeme tasarımında kullanılabileceği görülmüştür (Pratap ve ark., 2020).
Karbon bazlı malzemeler korozyon dayanımı gerektiren uygulamalarda, 1sı yalıtım uygulamalarında, sensor uygulamaları ve daha bir çok alandaki uygulamada ince ve hafif iletken bileşenler olarak yaygın olarak kullanılmaya başlanmıştır. Özellikle yüksek en-boy oranı ve düşük özgül ağırlığa sahip karbon allotropları araştırmacıların ilgi odağı haline gelmiştir. Nano ve üzerindeki bir boyuta sahip karbon bazlı iletken malzemeler çeşitli termoset/termoplastik ve elastomer matrisleri içerisine dolgu malzemesi olarak eklenip radar emici malzemeler olarak etkin bir şekilde kullanılabileceği araştırılmıştır (Vinoy ve ark., 1996).

Nano yapılı polimer kompozitler çok işlevli malzemeler için yeni perspektifler oluşturmuştur. Karbon nanotüp, karbon siyahı, grafen, fullerene gibi iletkenler havacılık uygulamalarına özel kompozitlerin mekanik ve elektriksel performanslarını geliştirmek için potansiyel uygulamalar sunmaktadır. Epoksi matrisi içerisine düşük konsantrasyonlarda karbon nanotüp (CNT) eklenmesi ile gelişmiş elektromanyetik özelliklere sahip yeni bir fonksiyonel malzeme elde edilmiş olup yalnızca $\% 0.5$ oranında CNT kullanılarak \%99.7'ye kadar mikrodalga emilimi sağlanmıştır (Silva ve ark., 2013). Cam elyaf/epoksi reçine ve grafen nano parçacıkları kullanılarak vakum destekli reçine transfer kalıplama ile üç bileşenli kompozit yapılar üretilmiştir. Grafen nano parçacıklarının düşük konsantrasyonlarda (ağırlıkça \%0.1) eklenmesi ile 8.2-12.4 GHz frekans aralığında elektromanyetik dalgaların geri yansımasında \%99.99'a varan bir zayıflama elde edilmiştir (Kunrath ve ark., 2019).

Son zamanlarda, telekomünikasyon sistemlerinin daha yüksek frekanslarda çalışması nedeniyle elektromanyetik dalga soğuruculara olan talep artmaktadır. Ferromanyetik ve iletken polimerik kompozitler, $2 \mathrm{GHz}$ ila $18 \mathrm{GHz}$ arasındaki frekans bölgesinde radar emici ve elektromanyetik koruyucu malzemeler olarak en az araştırılanlardır.

$\mathrm{Bu}$ çalışmanın amacı, dış mekan kullanımına uygun vulkanize nitril kauçuk sırt üzerine özel naylon ve iletken liflerden yapılmış multispektral radar emici malzemesi ile grafen/ karbon siyahı dolgulu hibrit doğal kauçuk karışımına lamine cam elyaf lamine edilerek üretilen katmanlı kompozit yapılar, yatay açılar $0-360^{\circ}$ arasında $3^{\circ}$ lik adımlarla, 6-17 GHz frekans değerleri arasında $1 \mathrm{Ghz}$ bant genişliğine sahip olacak şekilde, kapalı saha laboratuvar ortamında $26 \mathrm{~m}$ mesafeden radar kesit alanı özelliklerini karşılaştırmalı olarak araştırmaktır.

\section{Materyal ve Metot}

\subsection{Malzeme}

Radar kesit alanı azaltma testlerinde kullanılmak üzere dış mekan kullanımına uygun yeşil renkli ve halı yüzeyi desenli

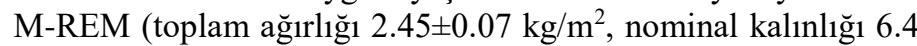
$\mathrm{mm}$, Radar yansıma kaybı (metal plaka üzerinde): ortalama 5-94 $\mathrm{GHz}$ frekans aralığında $15 \mathrm{~dB}$, Yakın kızıl ötesi yansıma 800$1700 \mathrm{~nm}$ arasında $>55 \%$ ) malzemesi Marktek Inc., ABD'den temin edilmiştir. $\mathrm{Bu}$ malzemeye alternatif olarak geliştirilen katmanlı kompozit (H-RGC) iletken dolgulu ve elastomer esaslı bir yapıya sahiptir. Matris bileşeni olarak kullanılan kauçuk grupları cis-izopren (SMR 20) ve cis-polibütadien kauçuk (CBR 1203), ana dolgu malzemesi karbon siyahı (FEF N550, ortalama parçacık boyutu $42-50 \mathrm{~nm}$, harici yüzey alanı $39 \mathrm{~m}^{2} / \mathrm{g}$, sıkıştırılmış numune yağ emme miktarı yaklaşık $85 \mathrm{~cm}^{3} / 100 \mathrm{~g}$ ) ve diğer ve katkı maddeleri (çinko oksit, stearik asit, CBS hızlandırıc1, parafinik yăg ve kükürt) USMER Kauçuk Ltd., Türkiye'den tedarik edilmiştir. İletken dolgu malzemesi olarak kullanılan grafen nanoplatetler (GF, \%99.9 saflığa, her parçacık 
kalınlığı 5 nm, Ortalama çapı 12-18 $\mu$ m, spesifik yüzey alanı $175 \mathrm{~m}^{2} / \mathrm{g}$ ve elektrik iletkenliği $1100-1600 \mathrm{~s} / \mathrm{m}$, renk gri) Nanografi Co., Türkiye'den tedarik edilmiştir. GF'ler düşük yoğunluk, yüksek en boy oranı, nano boyutlar ve ayarlanabilir elektriksel özellikleri sayesinde nanokompozitler için en umut verici nano boyutlu dolgu malzemeleri olarak bilinmektedir. Hazırlanan karışımdaki tüm bileşenler yüz birim kauçuk (phr) kısıma denk gelecek şekilde reçeteye dahil edilmiştir. H-RGC karışımına ait formülasyon tablo 1 'de gösterilmiştir.

Tablo 1. Hazırlanan kauçuk karışımına ait formülasyon

\begin{tabular}{l|c}
\hline Parametre & Miktar (phr) \\
\hline SMR 20 & 50 \\
\hline CNR 1203 & 50 \\
\hline FEF N 550 & 45 \\
\hline Grafen (GF) & 4 \\
\hline ZnO & 2.2 \\
\hline Stearic Acid & 2.6 \\
\hline IPPD & 1.2 \\
\hline TMQ & 1.3 \\
\hline Parafinik Yağ & 18.5 \\
\hline S80 & 2.45 \\
\hline CBS & 2.87 \\
\hline
\end{tabular}

H-RGC karışımı Farrel Markalı kapalı bir karıştırıcıda hazırlanmıştır. Kauçuk grubu, dolgu grubu ve diğer kimyasal bileşenler (hızlandırıcılar, plastikleştiriciler, yağ, vb.) (phr olarak), yirmi beş dakika boyunca $115{ }^{\circ} C^{\prime}$ de dâhili bir kapalı karıştırıcı kullanılarak kauçuk matrisine dâhil edilmiştir. Ardından çapraz bağlayıcı ve hızlandırıcılar eklenerek, homojen bir karışım elde edebilmek için yaklaşık beş dakika boyunca karıştırılmış sonrasında hazırlanan karışım dışarıya alınmıştır. Numune karışım, $23 \pm 2{ }^{\circ} \mathrm{C}$ sıcaklığında, $\% 50 \pm \% 5$ bağıl nemde (ASTM D412), 18 saat süre boyunca klimatik ortamda bekletilerek dinlendirilmiştir. Karışıma ait vulkanizasyon eğrileri, 8 dakika boyunca $165{ }^{\circ} \mathrm{C}$ 'de yapılan reometre testleri Montech MDR 3000, Almanya ile gerçekleştirilmiştir. Karışıma ait vulkanizasyon davranışlarını belirleyen minimum tork $\left(\mathrm{M}_{\mathrm{L}}\right)$, maksimum tork $\left(\mathrm{M}_{\mathrm{H}}\right)$, tork değeri $(\Delta \mathrm{M})$, kavurma süresi $\left(\mathrm{T}_{\mathrm{s} 2}\right)$, uygun kürlenme süresi $\left(\mathrm{T}_{\mathrm{c} 90}\right)$ gibi parametreler belirlenmiştir.

\subsection{Kompozit Malzemelerin Hazırlanması}

M-REM radar soğurucu malzeme hazır olarak satın alınmış olup vulkanize edilmiş nitril kauçuk üzerine özel yansıtıcı nikel kaplamalı elyaf ve cam elyaf ile birlikte polypropilen katmandan oluşmaktadır. $\mathrm{Bu}$ malzemeye ait fotoğraf şekil 1'de gösterilmiştir. M-REM toplam kalınlığı $6.2 \pm 0.2 \mathrm{~mm}$ olarak ölçülmüştür.

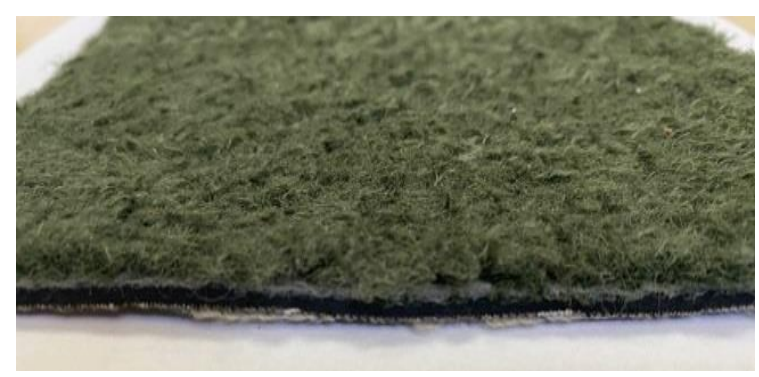

Şekil 1. M-REM radar soğurucu malzemesi
H-RGC radar soğurucu katmanlı kompozit yapı toplam kalınlığı $5.7 \pm 0.3 \mathrm{~mm}$ olup en dış katman cam elyaf, ardından yansıtıcı elastomer, PA6.6, iletken elastomer ve hibrid dolgulu elastomer karışımından oluşmaktadır. Malzemeler simetrik olarak yerleştirildiği için yön önemli değildir. H-RGC katmanlı kompozit radar soğurucu malzemeler şekil 2 de gösterildiği şekil ve sıralama ile hazırlanmıştır. Hazırlanan kompozit plakalar 200 ton kapasitesindeki hidrolik pişirme presinde, özel bir kalıplama yöntemi ile 22 dakika boyunca $180^{\circ} \mathrm{C}$ sicaklıkta vulkanize edilmiştir.

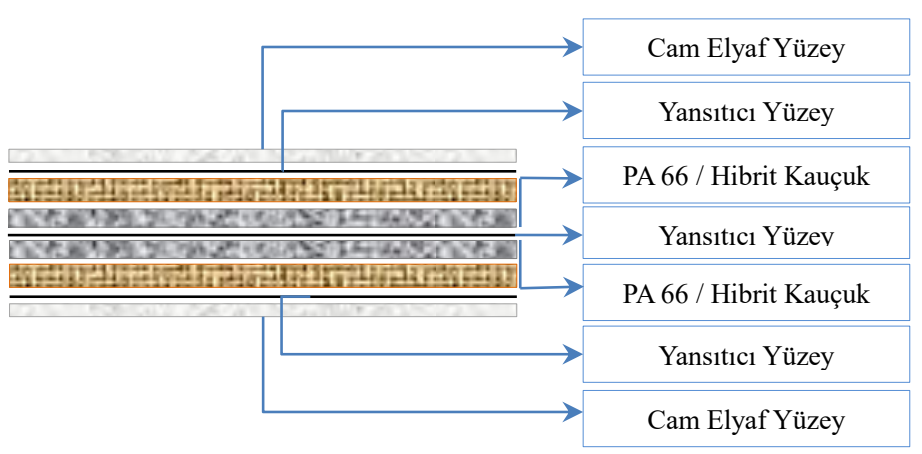

\section{Şekil 2. H-RGC radar soğurucu kompozit malzemesi detay gösterimi}

Vulkanize edilen H-RGC plakaları kalıptan çıktıktan sonra etrafındaki çapaklar temizlenerek $23 \pm 2{ }^{\circ} \mathrm{C} \quad$ sıcaklığında, $\% 50 \pm \% 5$ bağıl nemde (ASTM D412) 24 saat boyunca bekletildikten sonra kullanıma hazır hale getirilmiştir. Hazırlanan bu malzemenin dış yüzeyine ait fotoğraf şekil 3 'de gösterilmiştir.

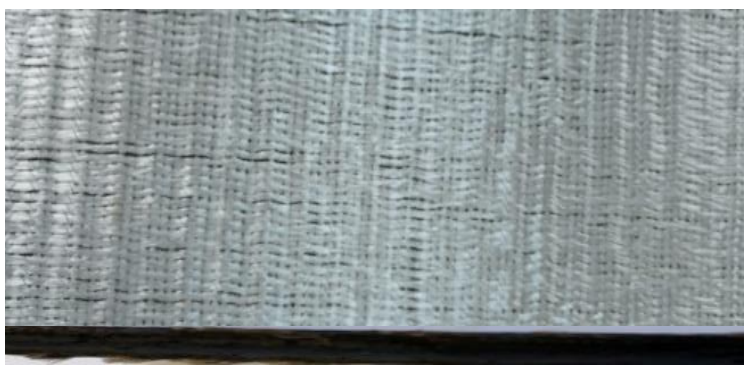

Şekil 3. H-RGC radar soğurucu malzemesi

Radar soğurucu malzemelerin RSA testlerini yapabilmek için her iki malzeme $57 \times 57 \times 3.5 \mathrm{~cm}$ ölçülerinde epoksi kaplanarak Şekil 4'de verilen kesit görüntüsü elde edilmiştir.
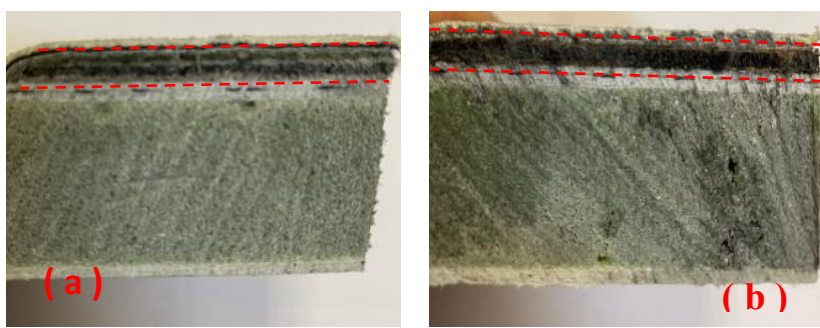

Şekil 4. Epoksi kaplanmış M-REM (a) ve H-RGC (b) malzemeleri kesit görüntüsü

RSA testine tabi tutulacak RAM'ların epoksi kaplandıktan sonra fiziksel uzunluğu $57 \mathrm{~cm}$ ve en yüksek ölçüm frekansı $18 \mathrm{GHz}$ olması sebebiyle, bu cismin uzak alan şartı 37.63 m'dir. RSA testleri TÜBİTAK Bilgem bünyesindeki yakın alan radar 
kesit alanı ölçüm merkezinde gerçekleştirilmiştir. TÜBİTAK Anten Test ve Araştırma Merkezi (ATAM) bünyesinde geliştirilen tomografi temelli yakın alan/uzak alan dönüşüm algoritması sayesinde, $26 \mathrm{~m}$ mesafeden RSA ölçümleri kapalı saha laboratuvar ortamında yapılmıştır.

\subsection{Uygulanan Ölçüm Yöntemi}

RSA ölçümüne başlamadan önce kalibrasyon hedefi olarak standart üçgen reflektör rotatör üzerine yerleştirilmiştir. Bant genişliği $1 \mathrm{GHz}$ olarak belirlendikten sonra menzil profil ölçümü alınmış ve numune dişında gelen yansımaları filtreleyebilmek için kullanılmıştır. Yapılan bu ölçümler sonucunda başlangıç ve bitiş değerlerine göre başlangıç kalibrasyon ölçümü yapılmıştır. Kalibrasyon ölçümleri yapıldıktan sonra yansıtıcı reflektör, rotatör üzerinden indirilerek, yerine RSA ölçümleri yapılacak olan numune bağlantı aparatı ile birlikte montaj edilmiştir. Numune yerleştirildikten sonra istenmeyen ekoların oluşmaması için bağlantı aparatı RF soğurucu özel sünger ile kaplanmıştır. RSA ölçümleri başlatılarak her bir merkez frekans etrafında $1 \mathrm{GHz}$ bant genişliği ile tarama yapılarak ham veriler toplanmıştır. Sonrasında numunenin yerine tekrardan kalibrasyon hedefi olarak standart üçgen reflektör, rotatör üzerine yerleştirilmiş ve bitiş kalibrasyon ölçümleri alınmıştır. Kalibrasyon arasındaki fark $2 \mathrm{~dB}$ 'den düşük çıkması durumunda ölçümlere devam edilmiştir. Kalibrasyon farkının $2 \mathrm{~dB}$ 'den fazla olduğu durumlar için ölçümler tekrarlanmıştır.

Alıcı antene gelen sinyaller bünyesinde kargaşa işaretlerini (çevre yansımaları), RF cihazların isıl gürültülerini ve test cisminden yansıyan sinyalleri beraberce barındırmaktadır. $\mathrm{Bu}$ nedenle cisme ait RSA ölçümlerinde yansıyan sinyallerin gücünün belirli bir eşik değerinden yüksek olmas1 gerekmektedir. Şekil 5'te $40 \mathrm{~cm}$ dik kenar uzunluğuna sahip standart üçgen reflektörün yaklaşık 26 metreden $18 \mathrm{GHz}$ merkez frekansındaki filtrelenmiş menzil profil grafiği verilmiştir.

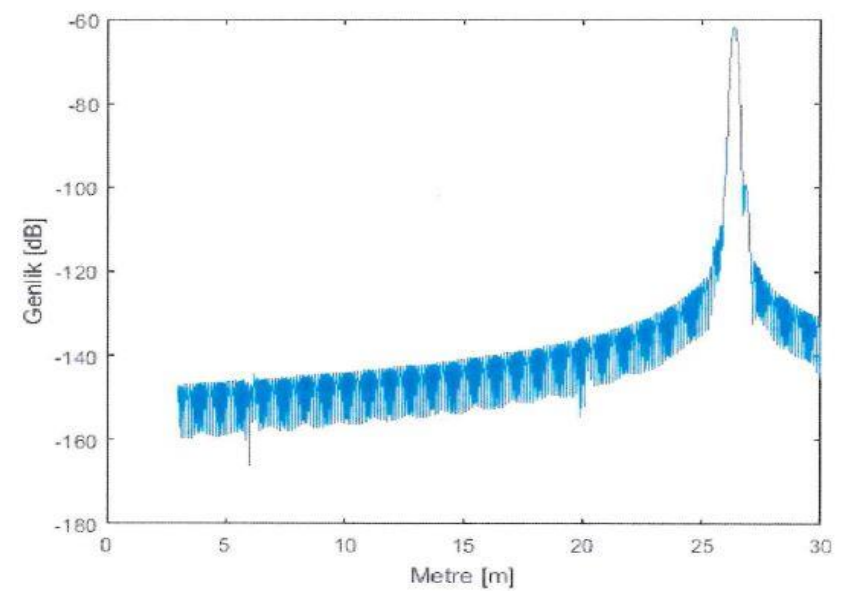

Şekil 5. Standart üçgen reflektör için $18 \mathrm{GHz}$ frekansındaki filtrelenmiş menzil profil grafiği

Anten test ve araştırma merkezi kapsamında yapılan RSA testlerinde verici ve alıcı olmak üzere iki adet kullanılmıştır. 1-18GHz bandında çalışabilen bu antenler, $18 \mathrm{GHz}$ 'de yatay ve düşeyde en az $25^{\circ}$ yarı güç hüzme genişliğine sahiptir ve kalibrasyon ihtiyacı bulunmamaktadır. Programlanabilir ölçüm analizörü, Agillent N5224B olup belirli bir frekans ve bant genişliğinde numuneye ait S21 parametresinin ölçülmesi için kullanılmıştır. Test numuneleri rotatör ismi verilen yata ve düşey açılarda hareketi sağlayan, elevasyon üzeri azimut yapısına sahip olup, küresel koordinat sisteminde hareket edebilmektedir.
Ölçüm parametreleri aşağıdaki şekildedir:

Yatay açı: $A Z=\left[0,360^{\circ}\right]$ aralığında $3^{\circ}$ adımlar ile

Düşey aç1: $\mathrm{EL}=90^{\circ}$

Frekans: 6-17 GHz,

Polarizasyon: Dikey-Dikey,

Averajlama: 64,

Yumuşatma (Smoothing): \%0,

Bant Genişliği: $1 \mathrm{GHz}$,

Örnekleme Sayısı: 2001

\section{Araştırma Sonuçları ve Tartışma}

Ölçümler numunelerin parlak yüzeyi antenlere yatayda $0^{\circ}$ (sıfır) derece açıyla bakacak şekilde alınmıştır. $180^{\circ}$ açıdayken numunelerin tam arka yüzeyi antenlere bakmaktadır. Mükemmel iletken bir yüzeye sahip ve numunelerle aynı boyutlarda olan bir kare plaka antenlere tam karşıdan bakarken ( yatay açı $0^{\circ}$ ve $180^{\circ}$ ) en yüksek RSA değerini vermektedir. Antenlere baktığg yatay açı değeri büyümeye başladıkça RSA değeri hızlı bir şekilde düşüş göstermektedir. Şekil 6, M-REM ile H-RGC malzemelerine 0 ila $360^{\circ}$ arasinda $3^{\prime}$ er derece aralıklar ile gönderilen elektromanyetik dalganın 6 ila $17 \mathrm{GHz}$ arasında elde edilen radar soğurucu malzemelere ait absorpsiyon eğrilerini göstermektedir. Her iki malzeme için de $11 \mathrm{GHz}$ 'de maksimum absorpsiyon ile bir rezonans davranışı sergilemiştir. M-REM ile hazırlanan RAM'da elde edilen ortalama RSA değeri 18.085 dBsm iken H-RGC ile hazırlanan RAM'da bu değer 17.584 dBsm olarak ölçülmüştür. M-REM malzemesine alternatif olarak hazırlanan H-RGC radar soğurma malzemesine 6-17 GHz frekans bant aralığında yapılan RSA test sonuçları incelendiğinde genel olarak bir benzerlik görülmektedir. Her iki malzeme arasındaki fark $13 \mathrm{GHz}$ frekansında $1,3323 \mathrm{dBsm}$ olarak gözlenmiştir. Ölçümlerde kullanılan cihazların kayıpları, kargaşa/gürültü sinyallerinin bozucu etkileri ve ölçüm algoritmasının hataları sebebiyle, ölçülen RSA değerlerinin 2 dB'lik toleransı vardır. Dolayısıyla, test cisminin üretim hassasiyeti mükemmel seviyede olsa bile, ölçüm sisteminin toleransı sebebiyle RSA değerlerinde 2 dB'lik salınımların olması beklenen bir durumdur.

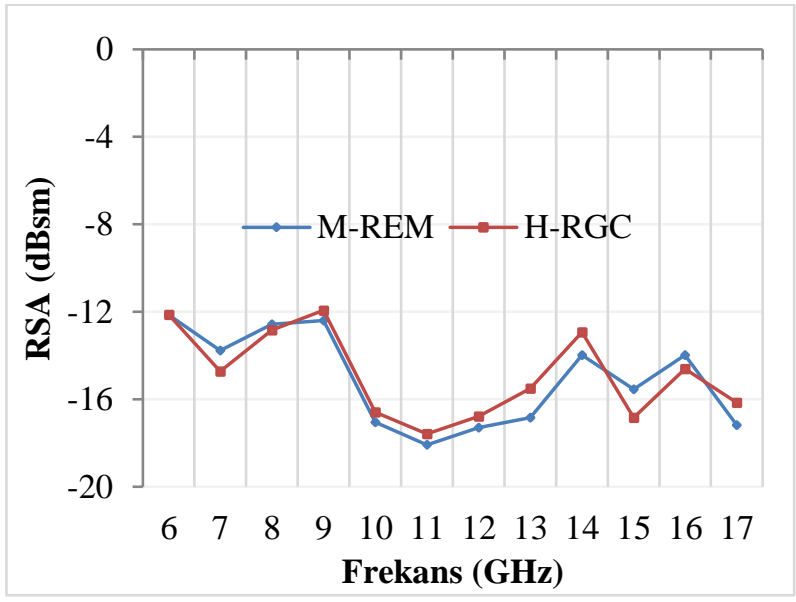

Şekil 6. RAM malzemelerinin frekansa bağll ortalama RSA de ğerleri 
Her iki malzeme içinde en yüksek RSA değerleri 0 derece yatay açılarda elde edilmiştir. Şekil 7'de açı ve frekansa bağlı en yüksek RKA değerlerinin karşılaştırma grafiği gösterilmiştir.

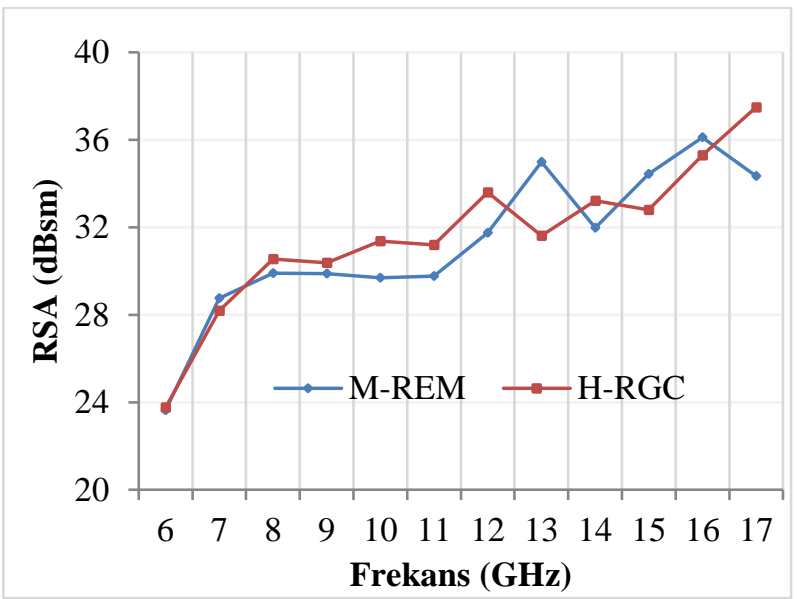

Şekil 7. $0^{\circ}$ yatay açıda RAM malzemelerinin frekansa bağlı RSA de ğerleri

Yatay açı değeri sıfır olduğunda M-REM malzemesi ile hazırlanan kompozitin $16 \mathrm{GHz}$ frekans değerinde $36,108 \mathrm{dBsm}$ RSA değeri ile maksimuma ulaşmıştır. H-RGC malzemesi ile hazırlanan kompozit yapı ise $17 \mathrm{GHz}$ frekans değerinde 37,4919 dBsm RSA değerine ulaş̧ıştır. Bununla birlikte her iki malzeme için $6 \mathrm{GHz}$ frekans değerinde RSA değerleri M-REM ve H-RGC için sırasıyla 23,6356 ve 23,7605 elde edilmiştir.

6-18 GHz arasındaki frekans değerlerinin her biri için, $0^{\circ}$ den $360^{\circ}$ ye kadar üçer derecelik artımlar ile yapılan RSA testlerinde elde edilen en düşük RSA değerlerine ait grafikler Şekil 8 ve Şekil 9'da gösterilmiş̧ir.

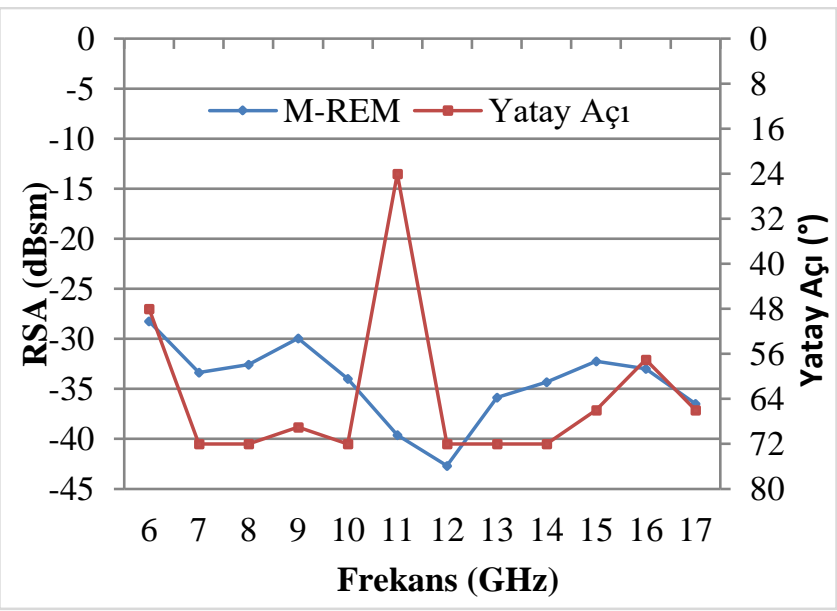

Şekil 8. Açı ve frekansa bağlı M-REM için en düşük RSA değerleri

M-REM radar soğurucu kompozit malzemesi için $6 \mathrm{GHz}$ frekans değerinde ve $48^{\circ}$ yatay açıda RSA değeri $28,2471 \mathrm{dBsm}$ olarak ölçülmüştür. Frekans bant genişliği arttıkça RSA özelliğinin de iyileştiği görülmektedir. $12 \mathrm{GHz}$ frekans için yapılan testlerde en düşük soğurma değeri $72^{\circ} \mathrm{de}, 42,6743 \mathrm{dBsm}$ olarak ölçülmüştür.

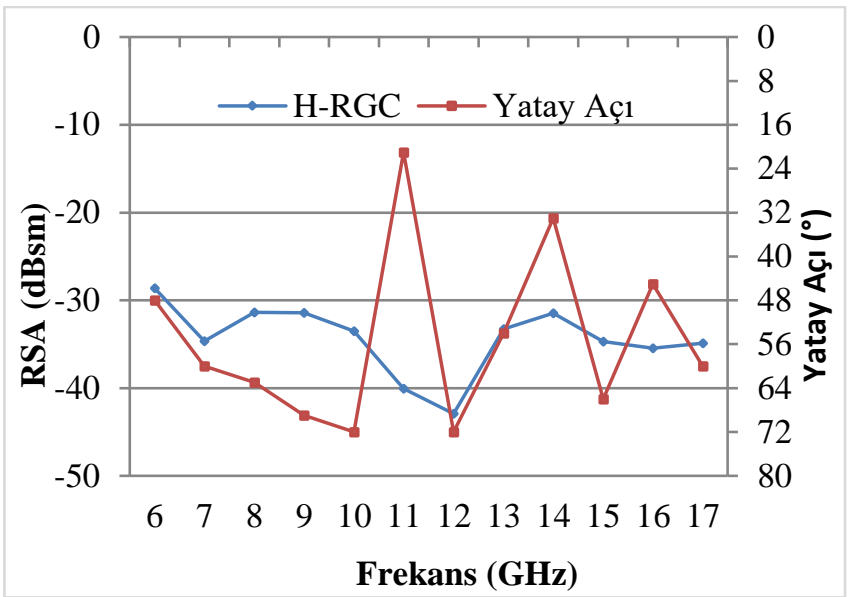

Şekil 9. Açı ve frekansa bağlı $H$-RGC için en düşük RSA değerleri

H-RGC radar soğurucu kompozit malzemesi için $6 \mathrm{GHz}$ frekans değerinde ve $48^{\circ}$ yatay açıda RSA değeri $28,6247 \mathrm{dBsm}$ olarak ölçülmüştür. İki malzeme için, aynı açıda $6 \mathrm{Ghz}$ frekans değerinde RSA değerleri oldukça benzerdir. $12 \mathrm{GHz}$ frekans için yapılan testlerde $72^{\circ}$ de, H-RGC için en düşük soğurma değeri olarak 42,9219 dBsm ölçülmüştür. Genel olarak her iki malzeme için RSA değerleri benzerlik gösterirken H-RGC malzemesinin daha geniş bir açı aralığında soğurma yapabildiği görülmüştür. M-REM için frekanstan bağımsız olarak en iyi RSA değerleri 24-72 ' 'ler arasında elde edilmişken, H-RGC için 21-72 aralığındadır.

Katmanlı bir yapıya sahip olan H-RGC'nin katmanları arasındaki iletken elastomerin içeriğindeki yapı elemanlarının miktarı ve uygulanma şekline bağlı olarak elektromanyetik sinyalleri yansitır. Yansiyan elektromanyetik dalgaların frekans1, yapı elemanlarının boyutuna ve şekline ve bunların levha yüzeyi üzerindeki dağılımına bağlıdır, yansıma işlemi ise yansıyan dalga frekansı ve yapı elemanı boyutları ile ilgili yasalara uyar (Sasria ve ark., 2017; Avloni ve ark., 2007). Yansitıcı karbon allotroplarının yeterli düzeyde olmaması durumunda nispeten düşük soğurma verimliliğine sahip bir malzeme olarak değerlendirilmektedir. Pratik kullanımlar için yeterli olarak değerlendirilen gelen radar enerjisinin \%10'undan daha azının yansitılması yatay açıya bağlı olarak 6-17 GHz frekans aralığında bu malzemede sağlanmıştır (Dedov ve ark., 2016).

Ölçümler sonucunda numunenin antenlere tam karşıdan baktığı durumdaki RSA değerlerinin, mükemmel iletken yüzeye sahip plakayla yakın değerler verdiğinin görülmesi ile numunelere RSA ölçümünden farklı olarak Açılı Yansitılıcık testleri yapılmıştır. Açılı Yansıtıcılık Testinde numune alıcı/verici antene 1,5 metre mesafeye yerleştirilmiştir. Ölçümler sırasında numuneler sabit kalırken antenlerin arasındaki açı değiştirilerek ölçümler yapılmıștır. Numune ile aynı boyutlardaki mükemmel iletken yüzeye sahip kare plakanın yansıma değerlerinden numunenin yansıma değerleri çıkartılarak numunelerin soğurganlık değerleri elde edilmiştir. Şekil 10'da M-REM ve HRGC malzemesi ile üretilen kompozit plakanın ön ve arka yüzeyine ait açılı yansitıcılık testi soğurganlık grafikleri gösterilmiştir. 

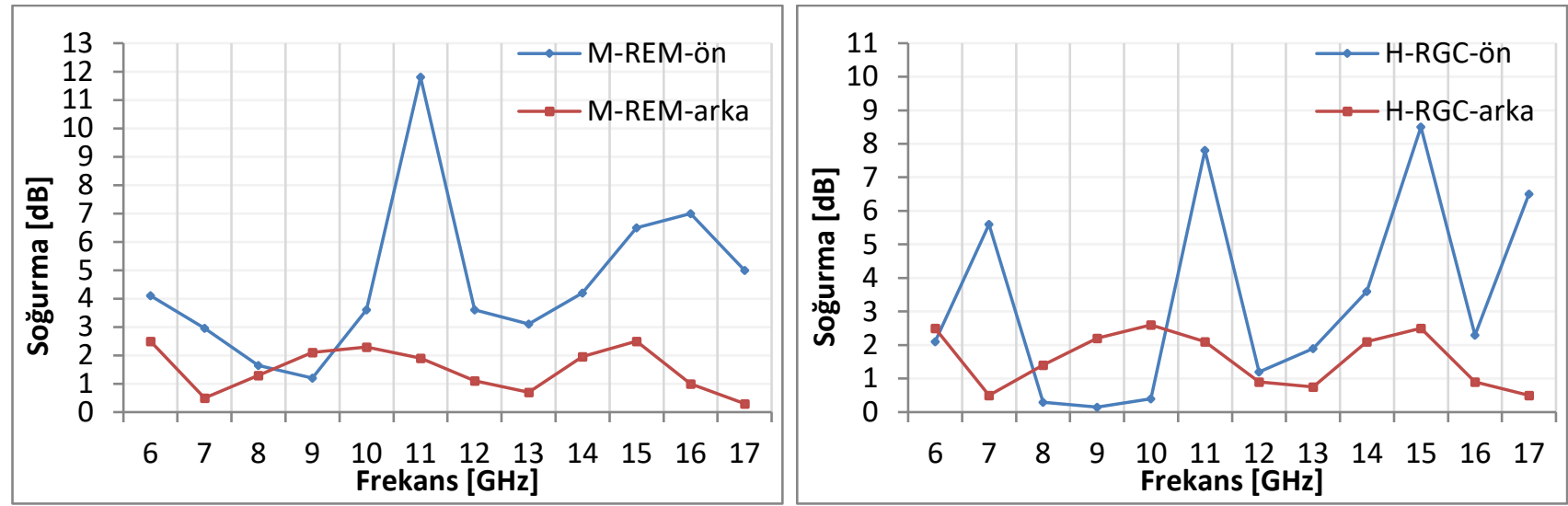

Şekil 10. M-REM ve H-RGC malzemesi açılı yansıtıcılık testi soğurganlık grafiği (antenler arası açı $5^{\circ}$ )

Paralel bir polarizasyonda gelen elektromanyetik dalganın geri saçılmasının artan açı değerine bağlı olarak azalması kompozit yapıların içerisinde barındırdıkları iletken dolguların elastomer yapısında oluşturdukları direnç ve kapasitans bileşenleri ile ilgili olduğu görülmüştür (Nalwa, 1997). Paralel polarizasyonda, geliş açısı ile kapasitans bileşeninde bir artı̧̧ ve buna bağlı olarak elektromanyetik dalganın geri saçılmasının azalma davranıı̧ında bir iyileşme gözlemlenmiştir (Wong ve ark., 1995). Şekil 11 ile Şekil 21 arasında M-REM $(6,2 \mathrm{~mm})$ ve H-RGC $(5,7 \mathrm{~mm})$ için karşılaştırmalı RSA test sonuçlarını gösterilmiştir. RSA testleri 6 $\mathrm{GHz}$ frekansından $18 \mathrm{GHz}$ frekansına kadar yapılmıştır.

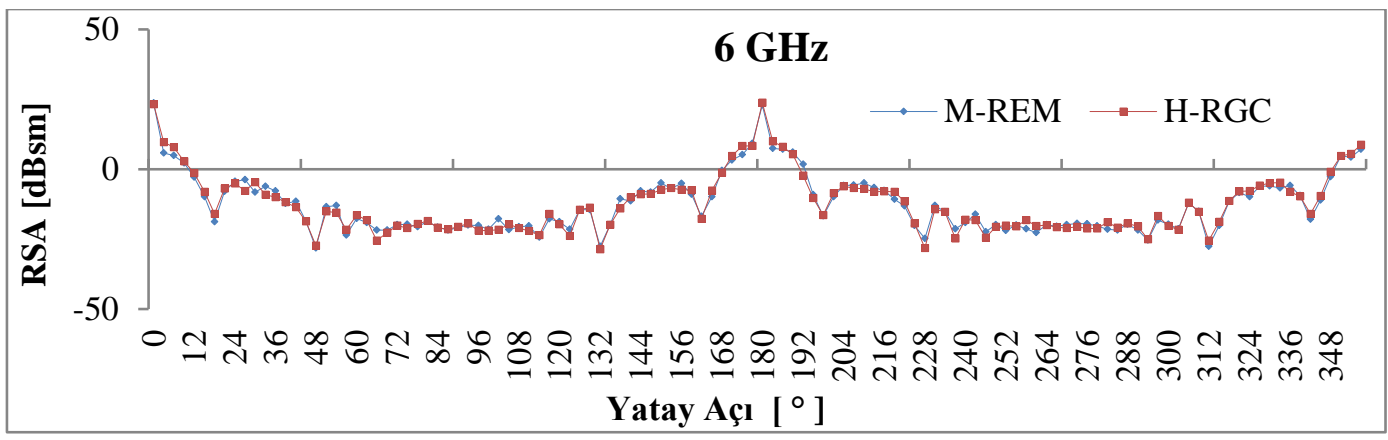

Şekil 10. M-REM ve H-RGC malzemelerinin $6 \mathrm{GHz}$ frekansında yatay açıya bağlı karşıllaştırmalı RSA grafikleri

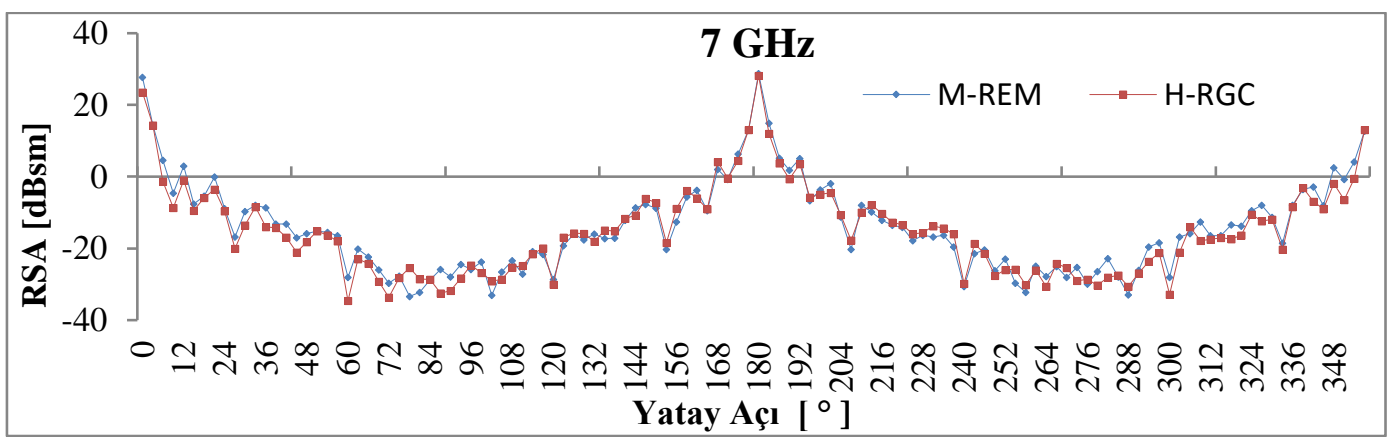

Şekil 11. M-REM ve H-RGC malzemelerinin $7 \mathrm{GHz}$ frekansında yatay açıya bağll karşılaştırmalı RSA grafikleri

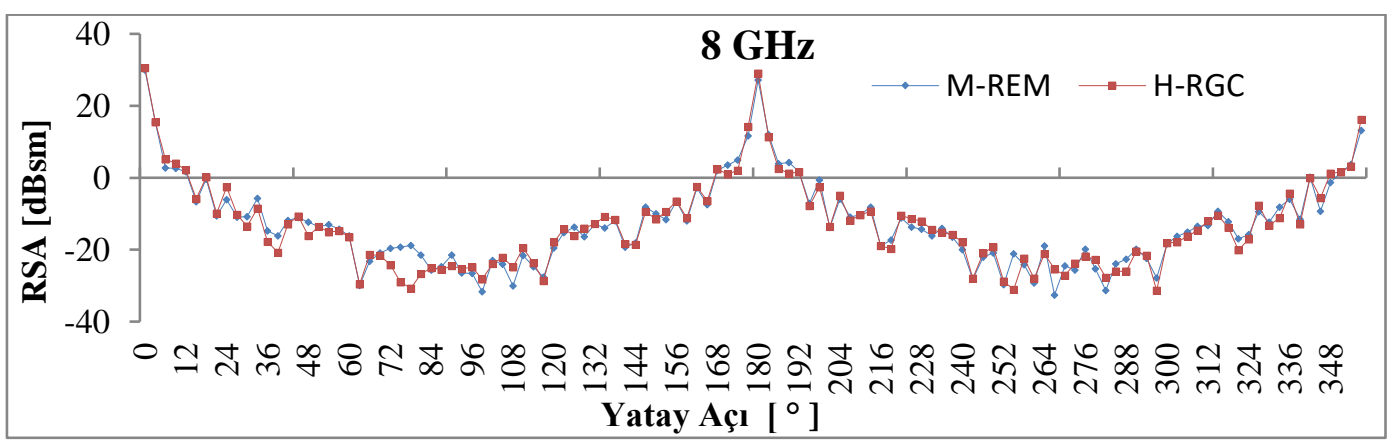

Şekil 12. M-REM ve H-RGC malzemelerinin $8 \mathrm{GHz}$ frekansında yatay açıya bağlı karşılaştırmalı RSA grafikleri 


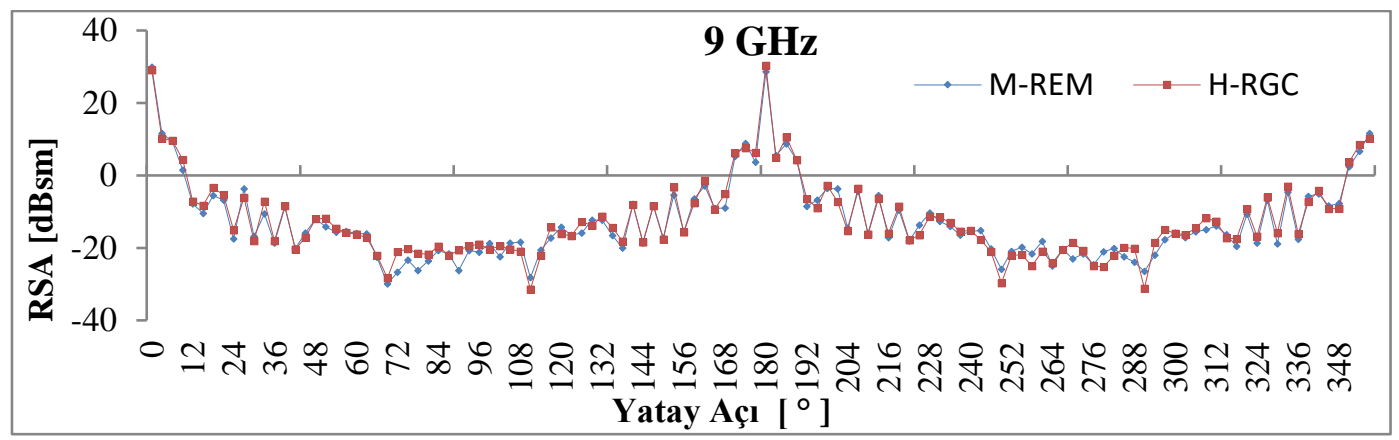

. Şekil 13. M-REM ve H-RGC malzemelerinin $9 \mathrm{GHz}$ frekansında yatay açlya bağlı karşılaştırmalı RSA grafikleri

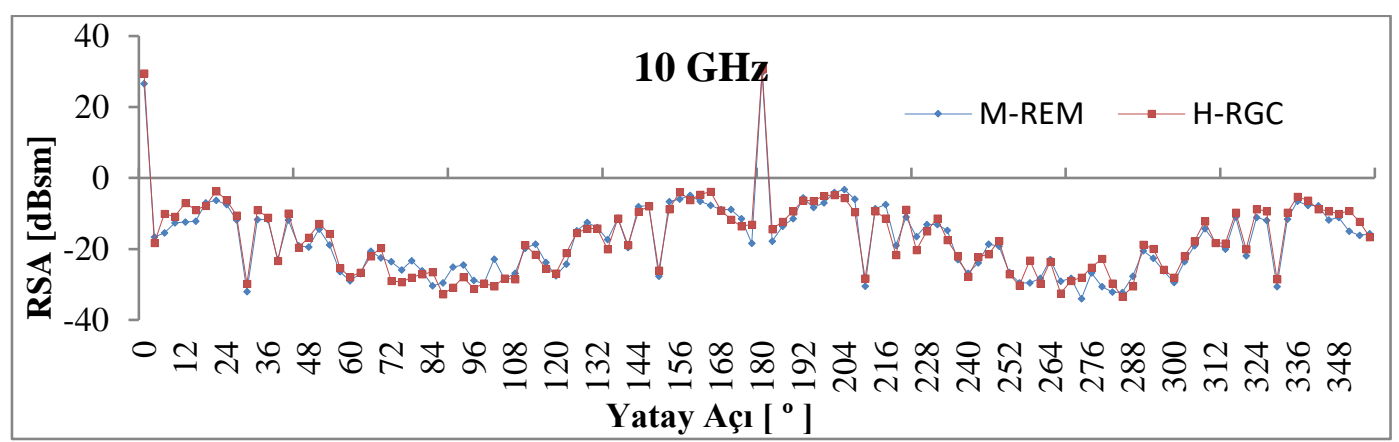

Şekil 14. M-REM ve H-RGC malzemelerinin $10 \mathrm{GHz}$ frekansında yatay açıya bağlı karşılaştırmalı RSA grafikleri

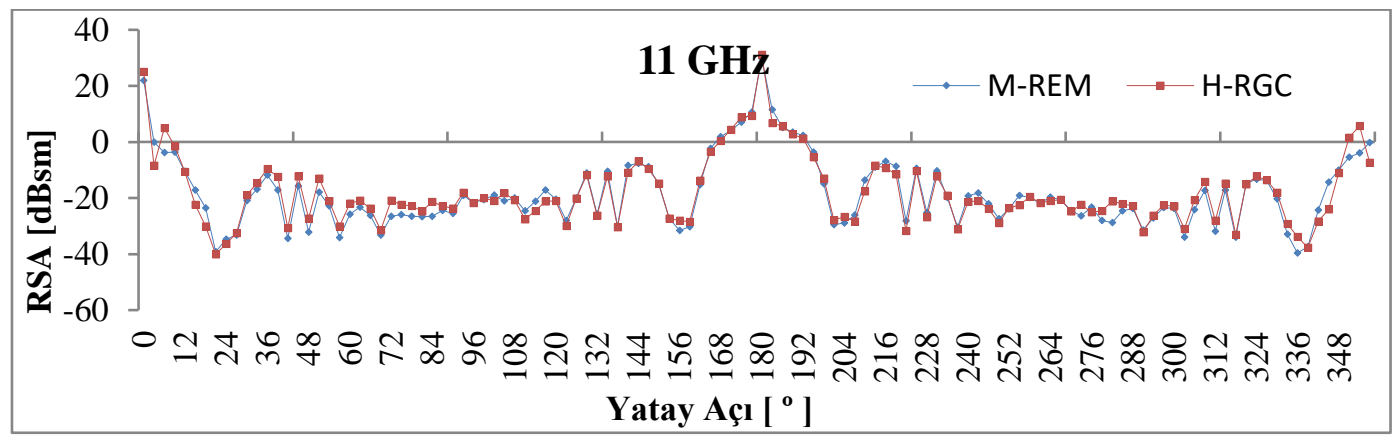

Şekil 15. M-REM ve H-RGC malzemelerinin $11 \mathrm{GHz}$ frekansında yatay açıya bağll karşılaştırmalı RSA grafikleri

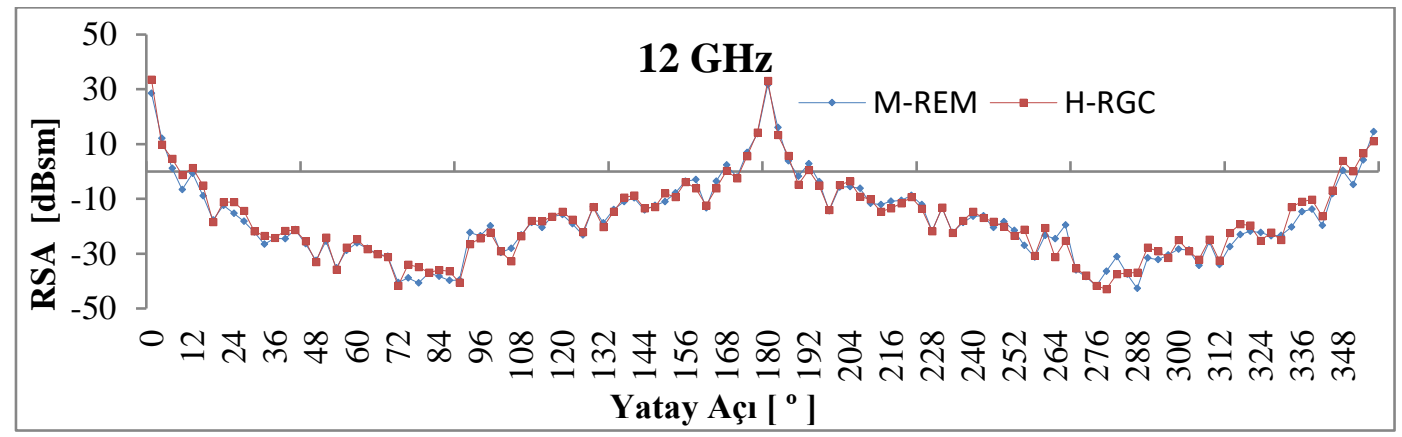

Şekil 16. M-REM ve H-RGC malzemelerinin $12 \mathrm{GHz}$ frekansında yatay açıya bağlı karşılaştırmalı RSA grafikleri

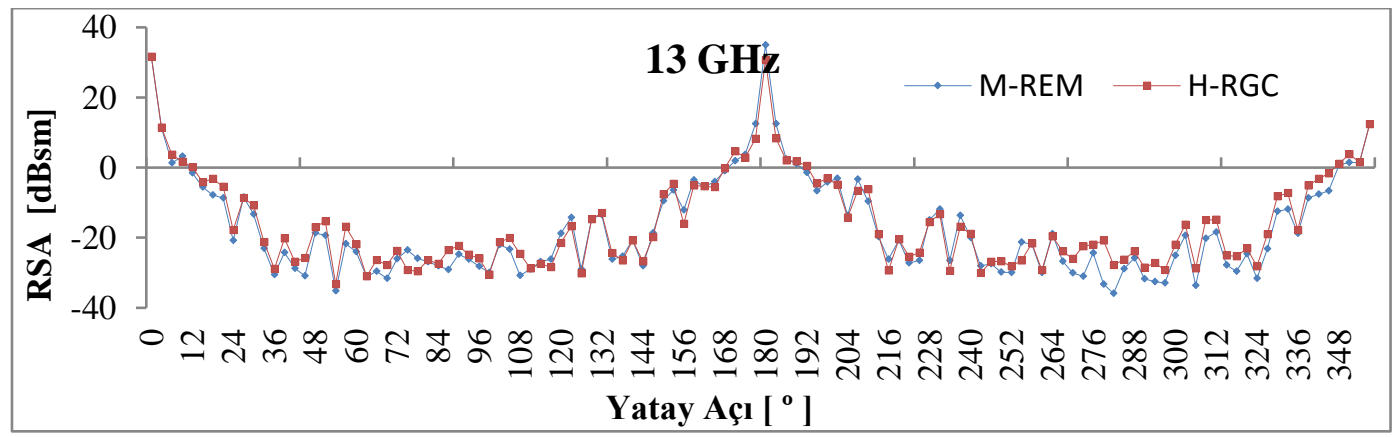

Şekil 17. M-REM ve H-RGC malzemelerinin $13 \mathrm{GHz}$ frekansında yatay açıya bağlı karşslaştırmalı RSA grafikleri 


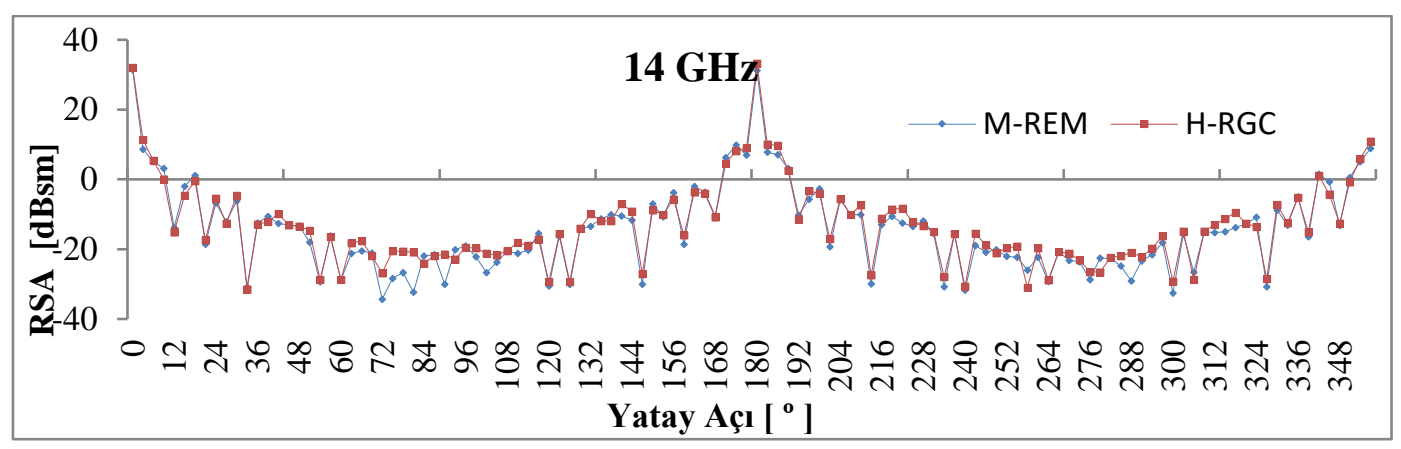

Şekil 18. M-REM ve H-RGC malzemelerinin 14 GHz frekansında yatay açıya bağlı karşılaştırmalı RSA grafikleri

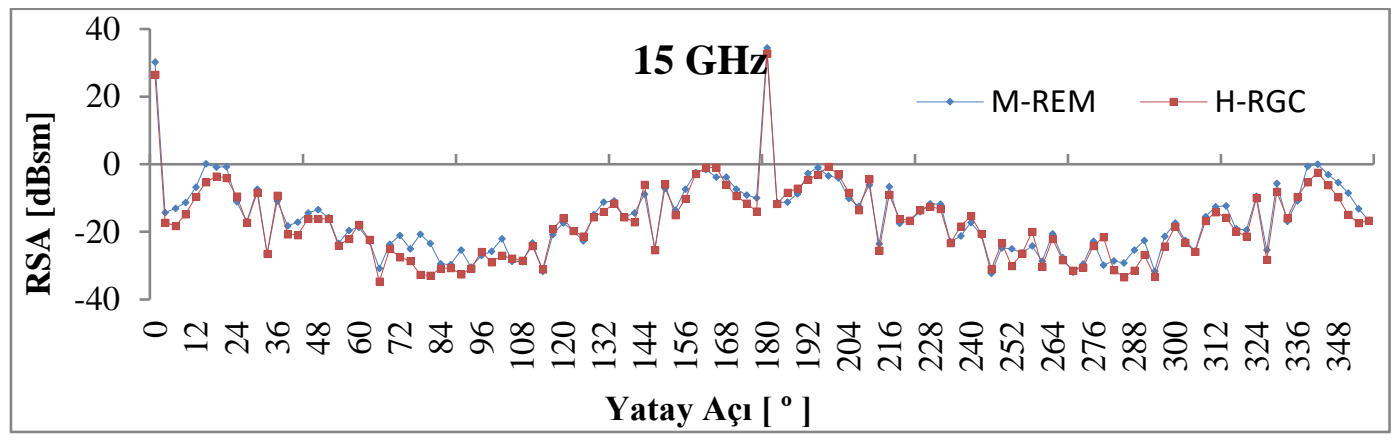

Şekil 19. M-REM ve H-RGC malzemelerinin $15 \mathrm{GHz}$ frekansında yatay açıya bağlı karşılaştırmalı RSA grafikleri

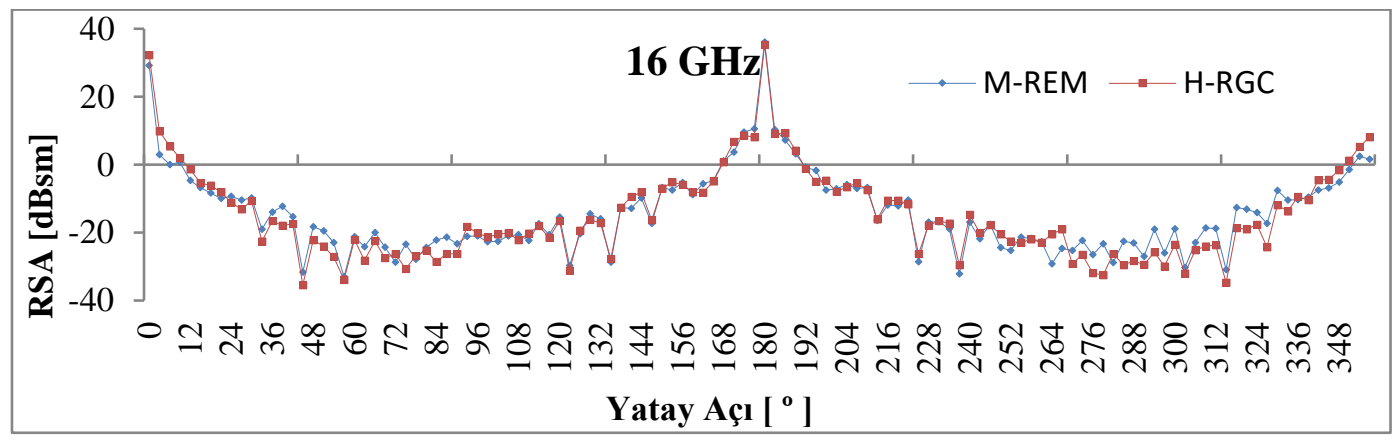

Şekil 20. M-REM ve H-RGC malzemelerinin $16 \mathrm{GHz}$ frekansında yatay açıya bağlı karşılaştırmalı RSA grafikleri

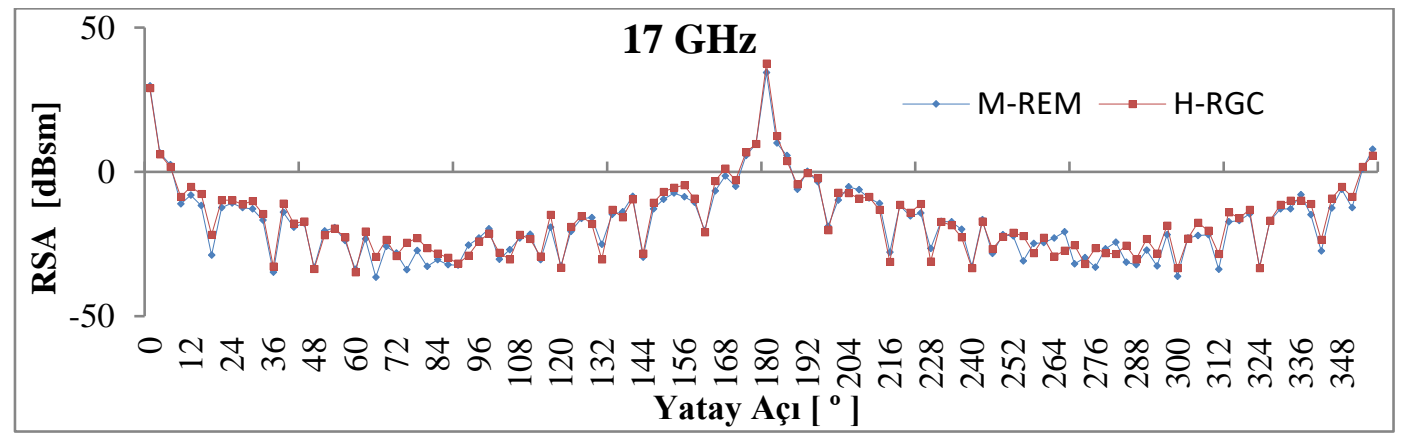

Şekil 21. M-REM ve H-RGC malzemelerinin $17 \mathrm{GHz}$ frekansında yatay açıya bağlı karşılaştırmalı RSA grafikleri

6-18 GHz frekans aralığında yapılan RSA testlerinde 60$120^{\circ}$ ve $240-300^{\circ}$ aralıklarında $20 \mathrm{dBsm}$ 'den daha az değerlerde sönümleme gerçekleşmiştir. M-REM malzemesinin $9 \mathrm{GHZ}$ frekansındaki testinde $60-120^{\circ}$ arasında ortalama değer 21,611 dBsm, $240-300^{\circ}$ arasında ortalama değer $21,025 \mathrm{dBsm}$ olup HRGC malzemesi için sırasıyla 20,678 ve 21,455 dBsm olarak ölçülmüştür. $10 \mathrm{Ghz}$ frekansında M-REM için belirtilen açı aralıklarında bu değerler 25,444 ve 26,922 dBsm, H-RGC için ise 27,100 ve $26,034 \mathrm{dBsm}$ olarak ölçülmüștür. Her iki malzeme için RSA değerleri birbirine çok yakın olup iki malzeme arasındaki fark 2 dBsm'nin altında ölçüm tolerans aralığında kalmıştır. Frekans bant genişliği artması ile RSA değerleri bir miktar daha iyileşmiştir. $17 \mathrm{GHz}$ frekans bandında M-REM malzemesinin RSA değeri $60-120^{\circ}$ arasında 28,026 dBsm , 240$300^{\circ}$ arasında $27,278 \mathrm{dBsm}, \mathrm{H}-\mathrm{RGC}$ malzemesi için sırasıyla 26,508 ve $26,203 \mathrm{dBsm}$ olarak ölçülmüştür. Değerler $3^{\circ}$ 'lik artımlardan elde edilen RSA değerlerinin ortalamasıdır. M-REM malzemesi, normal elektromanyetik dalga açısından daha yüksek açılarda iyi bir emilim sunar. Aynı davranış, H-RGC ile formüle edilmiş radar soğurucu malzeme içinde de gözlemlenmiştir. 


\section{Sonuç}

$\mathrm{Bu}$ çalışmada, radar soğurma malzemesi olarak ticari anlamda kendini kanıtlamış M-REM malzemesi ile iletken dolgular kullanılarak hazırlanmış elastomer esaslı H-RGC malzemesinin $1 \mathrm{GHz}$ bant aralıklarında, $3^{\circ}$ lik aralıklarda $0-360^{\circ}$ arasındaki radar kesit alanı ölçümlerinin deneysel olarak karşılaştırılması yapılmıştır.

Her iki RAM için yapılan ölçüm sonuçlarının birbirleri ile uyumlu olduğu gözükmektedir. Aradaki farkın ölçümlerde tam yansımasız oda koşullarının tam olarak sağlanmadığından ve üretim hatalarından kaynaklandığı değerlendirilmektedir. Elde edilen sonuçlar, nanokompozit temelli ışıma emici yapıların, mevcut haliyle gemi, askeri kara araçları gibi sistemlerde RSA azaltımında kullanılabileceğini göstermektedir.

H-RGC kompozitlerinin radar soğurma verimliliğinin iletken dolgu oranı, dolgu tipi ve karışım hazırlama yöntemlerine büyük ölçüde bağlı olduğu görülmüştür. Ayrıca, söz konusu radar soğurma malzemelerinin makro ve mikro yapı tasarımları sayesinde daha düşük maliyetli, kolay üretilebilir ve yüksek verimlilik özellikleri ile gizleme teknolojilerinde RSA azaltımında kendilerine yer bulabilecekleri değerlendirilmiştir.

Elektromanyetik dalgalar H-RGC kompozit plakalarına çarptığında $20 \mathrm{dBsm}$ değerinde bir azaltım sağlanabilmektedir. M-REM için frekanstan bağımsız olarak en iyi RSA değerleri $24-72^{\circ}$ arasında elde edilmişken, H-RGC için 21-72 aralığındadır. Bu değer radar dalgasının yüzeye çarpma açısına bağlı olarak daha da iyileşebildiği görülmüştür. H-RGC katmanlı kompozit plakasının dizilimi ve iletken yansıtıcı yüzeyi oluşturan elastomer karışım içerisinde kullanılan karbon esaslı dolgu malzemelerinin oranı ve tipi daha geniş açı aralıklarında etkili bir RSA elde etmek için değerlendirilebilir. Her iki RAM için frekans bant genişliği artıkça RSA değerlerinin de iyileştiği görülmüştür. M-REM için $12 \mathrm{GHz}$ frekans da yapılan testlerde en düşük soğurma değeri $72^{\circ} \mathrm{de}, 42,6743 \mathrm{dBsm}, \mathrm{H}-\mathrm{RGC}$ için en düşük soğurma değeri olarak 42,9219 dBsm ölçülmüştür. H-RGC'ler içerisindeki yansıtıcı yüzeylerdeki nanodolguların üç boyutlu ve karmaşık yapısı sayesinde daha geniş bir açı aralığında soğurma yapabildiği görülmüştür.

Gelecek çalışmalarda iletken nanodolgular ile hazırlanacak katmanlı kompozit yapıların RAM malzemesi olarak çok geniş bir aralıkta kullanılabileceği görülmüştür.

\section{Teşekkür}

$\mathrm{Bu}$ çalışma için gerekli olan kompozit numunelerin ve test ekipmanının kullanımını sağlayan Emsa Nano Teknoloji, Enerji San. ve Tic. A.Ş çalışanlarına teşekkür ederiz.

\section{Kaynakça}

Li Z.W., Yang Z.H., Kong L.B. (2010). Ultrabroad bandwidth of single-layer electromagnetic attenuation composites with flaky fillers. Applied Physics Letters, 90(9), 092507. https://doi.org/10.1063/1.3340460

Park K.Y., Lee S.E., Kim C.G., Han J.H. (2006). Fabrication and electromagnetic characteristics of electromagnetic wave absorbing sandwich structures. Composite Science and Technology 66(3-4), 576-84. https://doi.org/10.1016/j.compscitech.2005.05.034

Ren W, Nie Y, Xiong X, Zhang C, Zhou Y, Gong R. (2012). Enhancing and broadening absorption properties of frequency selective surfaces absorbers using FeCoBbased thin film. Journal of Applied Physics, 111(7), 07E703. https://doi.org/10.1063/1.3670980

Liu Q, Zhang D, Fan T. (2008). Electromagnetic wave absorption properties of porous carbon/Co nanocomposites. Applied Physics Letters, 93(1), 013110. https://doi.org/10.1063/1.2957035

Xu H., Bie S., Xu Y., Yuan W., Chen Q., Jiang J. (2016). Broad bandwidth of thin composite radar absorbing structures embedded with frequency selective surfaces. Composites Part A-applied Science and Manufacturing, 80, 111-117. https://doi.org/10.1016/j.compositesa.2015.10.019

Knott E., Shaeffer, J, Tuley, M. (2004). Radar Cross Section. SciTech Publishing Inc., Raleigh.

Badawy M.M, Zainud-Deen S.H.,Malhat H.A. (2020). RadarCross-Section Reduction Using Polarization Conversion Metasurface. 37th National Radio Science Conference (NRSC), 2020, pp. 66-73. doi: 10.1109/NRSC49500.2020.9235105.

Zhang L., Dong T. (2017). Low RCS and high-gain CP microstrip antenna using SA-MS. Electronics Letters, 53(6), 375-376. https://doi.org/10.1049/el.2016.4654

Kazantsev Y.N., Lopatin A., Kazantseva N., Shatrov, A.D., Mal'tsev V., Vilčáková J., Sáha P. (2010). Broadening of Operating Frequency Band of Magnetic-Type Radio Absorbers by FSS Incorporation. IEEE Transactions on Antennas and Propagation, 58(4), 1227-1235. DOI: 10.1109/TAP.2010.2041316

Shang Y., Shen Z., Xiao S. (2013). On the Design of SingleLayer Circuit Analog Absorber Using Double-Square-Loop Array. IEEE Transactions on Antennas and Propagation, 61(12), 6022-6029. DOI: 10.1109/TAP.2013.2280836

Franchitto M., Faez R., Orlando A.J.F., Rezende M.C., Martin I.M. (2001). Electromagnetic behavior of radar absorbing materials based on conducting polymers. Proceedings of the 2001 SBMO/IEEE MTT-S International Microwave and Optoelectronics Conference. (Cat. No.01TH8568), 2001, pp. 137-140 vol.1, doi: 10.1109/SBMOMO.2001.1008736.

Folgueras L.C., Rezende M.C. (2008). Multilayer radar absorbing material processing by using polymeric nonwoven and conducting polymer. Materials Researchibero-american Journal of Materials, 11(3), 245249. https://doi.org/10.1590/S1516-14392008000300003

Pratap V., Soni A.K., Siddiqui A.M., Abbas S.M., Katiyar R., Prasad N.E. (2020). Dielectric and Radar-Absorbing Properties of Exfoliated Graphite Dispersed Epoxy Composites. Journal of Electronic Materials, 49, 3972-3981. https://doi.org/10.1007/s11664-020-08118-6 
Vinoy K., Jha R. (2011). Radar Absorbing Materials: From Theory to Design and Characterization. Boston: Kluwer Academic Publishers.

Silva V.A., Folgueras L.C., Cândido G.M., Paula A., Rezende M.C., Costa M.L. (2013). Nanostructured Composites Based on Carbon Nanotubes and Epoxy Resin for Use as Radar Absorbing Materials. Materials Research-iberoamerican Journal of Materials, 16(6), 1299-1308. DOI: $10.1590 / \mathrm{S} 1516-14392013005000146$

Kunrath K., Kerche E.F., Rezende M.C., Amico S. (2019). Mechanical, electrical, and electromagnetic properties of hybrid graphene/glass fiber/epoxy composite. Polymers and Polymer Composites, 27(5), 262 - 267. https://doi.org/10.1177/0967391119828559

Sasria N., Ardhyananta H., Fajarin R., Widyastuti R. (2017). Synthesis and Characterization of BaFe12O19/Poly(aniline, pyrrole, ethylene terephthalate) Composites Coatings as Radar Absorbing Material (RAM). Journal of Physics: Conference Series, 877, 012057.

Avloni, D.J., Henn D.A. (2007). Development of New Conductive and Microwave-Lossy Materials Involving Conducting Polymer Coatings.

Dedov A.V., Nazarov V.G.(2016). Multilayer Radar Absorbing Non-Woven Material. Radiophysics and Quantum Electronics, 59(1), 43-47. https://doi.org/10.1007/s11141016-9674-x

Wong T.C.P., Chambers B., Anderson A.P., Wright P.V. (1995). Characterisation of conducting polymer-loaded composite materials at oblique incidence and their application in radar absorbers. Ninth International Conference on Antennas and Propagation, ICAP '95 (Conf. Publ. No. 407), 1995, pp. 441-444 vol.1, doi: 10.1049/cp:19950346.

Nalwa H.S. (1997). Conductive Polymers: Synthesis and Electrical Properties in Handbook of Organic Conductive Molecules and Polymers, v. 2, John Wiley \& Sons, New York. 